\title{
INTERNASIONALISASI USAHA MIKRO, KECIL, DAN MENENGAH (UMKM) DITINJAU DARI TIPE KEPEMILIKAN: STUDI EMPIRIS DI JAWA TIMUR
}

\author{
Herlina Yoka Roida, N. Agus Sunarjanto, dan William Jayaprana \\ Unika Widya Mandala Surabaya, email: yokaroida@yahoo.com.au
}

\begin{abstract}
In the internationalization process, scales do not become an obstacle among small medium SMEs. However, the capacity to get market access is the most important consideration based the type of SMEs ownership. This reach draws the impact of ownership types to invoice internationalization. The model analysis used in this research are: (1) model 1 used to determine whether or not SMEs to export, and (2) model 2 used to determine the intensity of SMEs in exports that control by innovation (R\&D expenditure), employment (SIZE) and sector choices. As a result, there is no significant impact of ownership type to the internationalization strategy. The decision mostly influenced by control variable which is sector choices, respectively.
\end{abstract}

Keywords: ownership types, propensity to export, export intensity, innovation ( $R$ \& D), labor (SIZE), sector

\section{PENDAHULUAN}

Selama ini mungkin UMKM hanya dianggap sebelah mata oleh masyarakat sebagai penggerak perekonomian namun jika ditinjau lebih jauh sesungguhnya peran UMKM itu sangatlah besar bagi penyerapan tenaga kerja dan memberikan domestik bruto bagi Indonesia. Harian KOMPAS (14 Desember 2007) menyebutkan penyerapan tenaga kerja di Indonesia mencapai 85 juta atau 96,18 persen dan kontribusi terhadap pendapatan domestik mencapai 52,28 persen, dengan adanya pernyataan ini kita dapat mengetahui peranan UMKM sangatlah besar untuk mengurangi masalah kemiskinan. Seiring dengan pertumbuhan jaringan dan komunikasi antar negara yang pesat sehingga membuka peluang untuk UMKM melakukan kegiatan internasionalisasi dalam bentuk ekspor, penanaman modal langsung (foreign direct investment), dan lisensi. Pada UMKM kegiatan internasionalisasi yang dapat mereka lakukan adalah di bidang ekspor dikarenakan minimnya modal keuangan yang dimilikinya, sehingga tidak memungkinkan UMKM untuk melakukan foreign direct investment dan lisensi, atau kecenderungan strategi 
internasionalisasi pada kegiatan padat karya dibanding dengan padat modal. Memang beberapa tahun terakhir hanya perusahaan - perusahaan besar yang melakukan kegiatan internasionalisasi, tetapi untuk sekarang tidak menutup kemungkinan untuk UMKM melakukan kegiatan internasionalisasi. Seperti yang disebutkan dalam penelitian Bonaccorsi (1992); Knight (2001); Lu dan Bearmish (2001) menyatakan bahwa ukuran dari bentuk usaha tidak menutup kemungkinan untuk melakukan kegiatan internasionalisasi, hanya saja pada UMKM akan mendapat kesulitan untuk melakukan inetrnasionalisasi dikarenakan mereka kesulitan untuk mendapatkan akses internasional.

Penelitian ini ingin mengetahui apakah suatu bentuk kepemilikan (ownership structure) memiliki hubungan terhadap keterlibatan UMKM dalam melakukan internasionalisasi. Bentuk kepemilikan merupakan salah satu faktor dalam UMKM untuk menentukan strategi yang mereka pakai untuk melakukan internasionalisasi, selain itu bentuk kepemilikan akan mempengaruhi suatu UMKM memiliki masalah agensi di suatu usaha tersebut sekaligus melihat seberapa besar risiko yang mereka ambil dalam mengambil suatu keputusan (Thomsen dan Perdersen, 2000) dan sumber daya yang mereka dapatkan (Shader dan Simon, 1997).

Bentuk kepemilikan (ownership structure) dapat dikategorikan menjadi kepemilikan keluarga yang dimana menjadi pemilik sekaligus manajer dalam usahanya sendiri tanpa ada campur tangan dari pihak luar, kepemilikan korporasi adalah kepemilikan yang terdiri dari beberapa orang dan mereka merekrut seorang manajer untuk mengendalikan perusahaan mereka, dan kepemilikan kombinasi antara keluarga dan sebagiannya lagi dimiliki oleh korporasi (corporate blockholder). Pemisahan bentuk kepemilikan perusahaan akan mempengaruhi perusahaan dalam pengambilan keputusan untuk melakukan internasionaliasasi. Secara garis besar, penelitian ini ditujukan kepada UMKM yang berada di propinsi Jawa Timur dan diharapkan dengan penilitian ini akan ada hal baru yang dapat membantu UMKM melakukan internasionalisasi.

\section{LANDASAN TEORI DAN PENGEMBANGAN HIPOTESIS}

Penelitian ini merupakan penelitian replikasi dari penelitian yang dilakukan oleh Fernandez dan Nieto (2006) dengan judul "Impact of ownership on the International Involvement of SMEs". Hanya saja fokus penelitian tersebut pada UMKM di negara Spanyol yang tentu saja memiliki perbedaan karakteristik dengan obyek penelitian yang ada dengan di Jawa Timur. Penelitian Fernandez dan Nieto menggunakan metode probit pada model pertama yang di gunakan untuk mengetahui apakah sebuah UMKM mengambil keputusan untuk melakukan 
ekspor atau tidak. Sedangkan model kedua menggunakan motode tobit untuk menganalisis determinan dari export intensity. Pada kedua model digunakan data panel.

Pada model 1 ini medukung hipotesis pertama mengenai keterlibatan internasional UMKM berhubungan negatif dengan bentuk kepemilikan keluarga (family ownership), begitu pula untuk hipotesis kedua dan hipotesis ketiga jua di dukung oleh model yang kedua ini. Untuk model export intensity ini menunjukkan bagaimana berbagai jenis kepemilikan memiliki pengaruh terhadap intensitas ekspor. Pada model 2 ini semua variabel yang dimasukkan dalam model ini secara signifikan terkait dengan variabel dependen dengan tingkat kesalahan $10 \%$ dan model signifikan pada level $1 \%$.

Variabel kontrol yang digunakan pada model kedua yaitu aliansi dan inovasi yang diduga memiliki mempunyai hubungan yang positif dan signifikan terhadap intensitas ekspor. Hasil ini mengkonfirmasi bahwa inovasi yang kompetitif merupakan faktor penting yang dapat menjelaskan perilaku ekspor UMKM. Usia perusahaan signifikan dalam menciptakan keahlian dan mengumpulkan sumber daya yang mempromosikan keterlibatan internasional. Sedangkan variabel kontrol lainnya yaitu size, foreign dan sektor berpengaruh positif terhadap rasio penjualan ekspor. Penelitian diatas berdasarkan sampel longitudinal mewakili UMKM Spanyol mengkonfirmasi adanya hubungan yang signifikan antara jenis kepemilikan dan intensitas ekspor.

Studi mengenai kebutuhan untuk menganalisis bagaimana jenis kepemilikan mempengaruhi perilaku strategis perusahaan juga dilakukan oleh Thomsen dan Pederson (2000). Kepemilikan keluarga memiliki kelebihan dan kekurangan tertentu pada perusahaan (Kets de Vries, 1996; Poza, 2004). Dalam kasus ini, aspek negatif dari kepemilikan keluarga tampaknya lebih besar daripada keuntungan yang diperoleh oleh perusahaan. Perusahaan yang dimiliki keluarga lebih sulit untuk membangun sebuah portofolio sumber daya strategis sehingga membuatnya kesulitan untuk mampu bersaing di pasar luar negeri.

Strategi Internasionalisasi

Dalam penelitian yang dilakukan Fernandez dan Nieto (2006), Buckley dan Casson (1976) dan Dunning $(1977,1981)$ menyatakan bahwa strategi intenasionalisasi secara konsep dan teori dapat dibagi menjadi dua yaitu teori internalisasi (internalization theory) dan electic theory. Teori internalisasi muncul dikarenakan berkembangnya perusahaan besar pada era tahun 1970 yang dapat mengancam keberadaan UMKM. Selanjutnya dalam 
perkembangannya, teori ini berusaha menginternalisasi keuntungan yang dapat diperoleh dari internasionalisasi, lokalisasi, dan kepemilikan. Sedangkan ecletic theory dalam strategi internasionalisasi lebih menekankan pada sumber daya yang dimilikinya dan pengetahuan UMKM dalam menentukan pasar dan jaringan yang akan dipilih dalam memasarkan produknya.

Proses internasionalisasi dapat dipandang sebagai suatu proses belajar sebuah UMKM. Beberapa aspek mengenai internasionalisasi seperti usia (age) UMKM, Ukuran (size) UMKM, dan sektor indutri yang dipilih UMKM menjadi bahan kajian yang sudah dilakukan oleh beberapa peneliti di negara lain (Fernandez dan Nieto, 2006). Strategi internasionalisasi UMKM perlu juga memperhatikan aspek kepribadian akan sangat berpengaruh dalam menentukan capaian kerja UMKM dalam menjalankan strategi internasionalisasi UMKM. Bahasan inilah sebenarnya yang menjadi salah satu elemen baru yang perlu dipertimbangkan dalam menjalankan strategi internasionalisasi yaitu yang berkaitan dengan bentuk keepemilikan UMKM.

\section{Biaya Keagenan Pada Usaha Kecil}

Masalah keagenen dalam rumusan teori yang dikemukakan oleh Jensen dan Mecling (1976) menyatakan bahwa pemisahan antara pemilik dan manajer berpotensi memunculkan masalah keagenan. Masalah keagenan muncul akibat adanya pemisahan antara pemilik dan manajer. Pemisahan ini berkonsekuensi pada munculnya biaya yang ditimbulkan untuk melakukan monitoring kegiatan perusahaan yang dilakukan oleh pemegang saham terhadap manajer. Biaya monitoring tersebut merupakan biaya keagenen yang muncul dalam pengelolaan perusahaan.

Pada usaha kecil, umumnya pemilik mengambil peran sekaligus sebagai manajer dalam struktur manajemen perusahaan. Dalam kondisi ini, umumnya biaya keagenen tidak ditemukan atau disebut sebagai zero agency cost case (Ang et.al, 2000). Namun apabila pada perusahaan kecil yang merekrut manajer dari luar maka masalah keagenan dapat timbul sebagai residual agency cost (Fama dan Meckling 1976 dalam Ang et.al, 2000) yaitu biaya keagenan tidak murni seperti masalah agensi yang muncul pada perusahaan yang memisahkan kepemilikan dengan manajemen perusahaan. Jika pemilik sekaligus menjadi manajer suatu usaha maka biaya yang dikeluarkan untuk masalah agensi menjadi cenderung ditiadakan. 
Tidak adanya biaya keagenan pada usaha kecil juga didukung oleh teori yang dikemukakan oleh Jensen dan Meckling (1976) dan Fama dan Jensen (1983). Selain itu hasil penelitian yang dilakukan oleh Ang et.al (2000) yang menyimpulkan bahwa semakin banyaknya pemilik yang menjadi manajer dalam usaha kecil akan berbanding terbalik dengan biaya agensi yang dikeluarkan untuk mengatasi masalah agensi. Sehingga apabila kepemilikan usaha yang dimiliki 100 persen keluarga dan sekaligus menjadi manajer 100 persen pula maka tidak akan ada biaya agensi yang muncul.

Tipe Kepemilikan

Bentuk kepemilikan dibedakan menjadi: kepemilikan keluarga (family), korporasi (corporate), dan kepemilikan keluarga dan korporasi (family and corporate) atau system blockholer. Bentuk kepemilikan ini akan menentukan strategi UMKM dan kinerjanya yang berhubungan dengan drajat penerimaannya atas risiko dalam pengambilan keputusan. Studi mengenai keterkaitan bentuk kepemilikan dan perilaku strategik UMKM masih sangat terbatas, sementara bentuk kepemilikan akan sangat berpengaruh dalam sistem insentif dan kontrol atas operasional suatu usaha.

Dalam penelitian Fernandez dan Nieto (2006), kepemilikan kelvarga (family ownership) memiliki beberapa keunggulan (Poza, 2004) yaitu orientasi jangka panjang fleksibilitas, kecepatan pengambilan keputusan, serta kultur keluarga yang berakar pada komitmen dan kebanggaan. Namun begitu bentuk kepemilikan ini memiliki beberapa kelemahan terutama pada akses pendanaan eksternal dan akses sumber daya yang diperlukan untuk kelangsungan usaha terutama mengenai asset berbasis pengetahuan yang intangible yaitu teknologi, merek yang jarang dikenal dan keterbatasan kapabilitas sumber daya manusia. Disamping itu konflik kepentingan antara kepentingan usaha dan kepentingan pribadi menjadi sangat kabur dalam bentuk kepemilikan ini. Umumnya UMKM yang dimiliki oleh keluarga memiliki sumber daya manusia yang relatif tidak memiliki pengalaman secara internasional. Pengambilan keputusan keuangan juga akan tergantung pada perimbangan kepentingan keluarga yang tetap independen dari kontrol pihak lain atau dengan kata lain sebagai konsekuensi untuk tidak membawa masuk pemiliki baru dalam usahanya. Hambatan ini manjadikan UMKM dengan family ownership tidak memiliki keterlibatan secara internasional dalam perilaku strategiknya.

Bentuk kepemilikan korporasi (corporate ownership) memungkinkan akses pendanaan yang lebih luas karena adanya jaminan dari pemegang sahamnya. Bentuk kepemilikan ini juga memungkinkan UMKM mendapat akses teknologi, komersial maupun pengetahuan 
organisasional (Allen dan Phillips, 2000). Struktur organisasi yang baik, kendali atas kualitas produk yang tinggi dan efisiensi dalam pemilihan manajemen organisasi. Kondisi ini memungkinkan akses yang lebih luas untuk masuk ke pasar modal dalam hal pendanaan maupun motivasi menjalankan strategi internasionalisasi yang lebih besar.

Blockholder ownership atau kepemilikan keluarga dengan sebagian dimiliki oleh pihak luar memungkinkan, bentuk kepemilikan seperti ini mendapatkan beberapa keuntungan dibandingkan dengan dua bentuk kepemilikian sebelumnya yaitu pertama, corporate blockholer akan membantu dalam strategi untuk menghadapi pasar luar negeri terutama mengenai masalah sumber daya. Kedua, corporate blockholder memungkinkan untuk membantu pemecahan masalah konflik kepentingan dalam sistem kepemilikan keluarga yang relatif tradisional. Melalui pembagian kepemilikan tersebut, bentuk kepemilikan ini akan mampu untuk menjalankan strategi internasionalisasi dan mampu bersaing secara global lebih kuat dibandingkan dengan dua kepemilikan lainnya.

Hipotesis

Penelitian yang dilakukan oleh Fernandes dan Nieto (2006) di Spanyol menyimpulkan bahwa UMKM yang dimiliki oleh keluarga memiliki sumber daya manusia yang relatif kurang pengalaman akan proses internasionalisasi yang mereka lakukan. Berdasarkan hal tersebut maka dapat disimpulkan :

Hipotesis 1 : Internasionalisasi UMKM berhubungan negatif dengan bentuk kepemilikan kelvarga (family ownership)

Pada bentuk kepemilikan korporasi, UMKM memiliki kemampuan yang dapat memudahkan mereka untuk melakukan kegiatan internasionalisasi (Allen dan Phillips, 2000). Berdasarkan hal tersebut maka dapat disimpulkan :

Hipotesis 2 : Internasionalisasi UMKM berhubungan positif dengan bentuk kepemilikan korporasi (corporate ownership)

Sedangkan pada bentuk kepemilikan campuran, UMKM juga tidak memiliki kesulitan dikarenakan adanya bantuan dari pihak luar selain keluarga untuk membantu mereka dalam melakukan kegiatan internasionalisasi. Sehingga dugaan yang dapat dibentuk adalah :

Hipotesis 3 : Internasionalisasi UMKM berhubungan positif dengan bentuk kepemilikan campuran (blockholder ownership) 


\section{METODE PENELITIAN}

Penelitian ini menggunakan hipotesis dimana rancangan penelitian menggunakan kuesioner yang di bagikan kepada usaha mikro yang berada di Jawa Timur yang total berjumlah 2.910 UMKM yang melakukan internasionalisasi (ekspor) maupun UMKM yang pangsa pasarnya hanya regional, tetapi dari 2.910 diambil sampel sebanyak 315 UMKM. Penelitian ini menekankan pada pengujian hipotesis yang menyatakan suatu hubungan.

Dalam penelitian ini terdapat dua variabel dependen, tiga variabel independen, dan enam variabel kontrol yang digunakan, yaitu :

a) Propensity to export (PEXP) sebagai variabel dependen, yang mengindikasikan apakah usaha mikro di Jawa Timur melakukan export atau tidak.

b) Export intensity (EXPINT) sebagai variabel dependen, yaitu suatu ukuran ratio penjualan eksport terhadap total penjualan usaha mikro di Jawa Timur dan dituliskan dalam bentuk persentase. Sehingga export intensity dapat dihitung dengan rumus sebagai berikut :

$$
\text { Export Intensity }=\frac{\text { Penjualan export pada Tahun } n}{\text { Total Penjualan pada Tahun }}
$$

c) Family (FAM) sebagai variabel indedependen, yaitu usaha mikro yang dikelola oleh satu atau beberapa anggota keluarga.

d) Corporate (COR) sebagai variabel indedependen, yaitu usaha mikro yang dimiliki oleh blockholder kepemilikan korporasi.

e) Campuran (FAMCOR) sebagai variabel indedependen, yaitu usaha mikdo yang dimiliki oleh kombinasi keluarga dan blockholder kepemilikan korporasi.

f) Inovasi (R\&D) sebagai variabel kontrol, yaitu variabel yang menjelaskan kinerja ekspor dan untuk mengontrol dampak inovasi dalam perilaku strategik. Pada penelitian terdahulu dan kebanyakan penelitian lainnya, menyimpulkan inovasi merupakan faktor penting dalam menjelaskan kinerja ekspor (Ito and Pucik, 1993; Wakelin, 1998; Molero, 1998; Basile, 2001). Untuk mengetahui rasio pengeluaran yang dikeluarkan UMKM untuk melakukan inovasi dibandingkan dengan total penjualan dan dituliskan dalam bentuk persentase. Sehingga, dari rumusan tersebut dapat dirumuskan sebagai berikut :

$$
\operatorname{Inovasi}(R \& D)=\frac{\text { Pengeluaran Inovasi pada Tahun } n}{\text { Total Penjualan pada Tahun } n}
$$


g) Size (SIZE) sebagai variabel kontrol, yaitu penggunaan tenaga kerja sebagai variabel kontrol disebabkan UMKM cenderung padat karya dibandingkan dengan padat modal sehingga besar kecil nya suatu UMKM dapat diukur dari banyaknya jumlah tenaga kerja yang dimiliki.

h) Sektor (SECTOR) dipilih sebagai variabel kontrol dikarenakan adanya hubungan antara sumber daya yang dimiliki oleh UMKM baik sumber daya keuangan dan kemampuan personel UMKM dengan pilihan sektor yang dipilih. Pemilihan sektor yang sesuai dengan sumber daya yang dimiliki akan menempatkan kekuatan daya saing UMKM dalam melakukan eksport.

\section{HASIL DAN PEMBAHASAN}

Dikarenakan keseluruhan tipe kepemilikan UMKM yaitu kepemilikan keluarga dan tidak adanya bentuk kepemilikan korporasi (corporate ownership) dan campuran (blockholder ownership) pada responden yang akan kita teliti, sehingga untuk selanjutnya penelitian ini hanya akan menguji hipotesis pertama dan mengabaikan hipotesis kedua dan ketiga yang ingin mengetahui pengaruh bentuk kepemilikan korporasi dan campuran terhadap pengambilan keputusan internasionalisasi UMKM dikarenakan tidak terdukungnya data yang mampu menjawab hipotesis kedua dan ketiga.

Tabel. 1

Model Empiris

\begin{tabular}{|c|c|c|}
\hline & PEXP (Model 1) & EXPINT (Model 2) \\
\hline \multicolumn{3}{|l|}{ Kepemilikan Keluarga } \\
\hline Inovasi & 0.996 (1808.552) & $0.153(-2.766)$ \\
\hline Tenaga Kerja & $0.139(0.008)$ & $0.384(-0.001)$ \\
\hline Sektor UMKM & $0.000 *(-0.479)$ & $\begin{array}{c}\text { DSektor } 1: 0.686(0.56) \\
\text { DSektor } 2: 0.094(-0.254) \\
\text { DSektor } 3: \mathbf{0 . 0 3 7 *}(-\mathbf{0 . 3 0 8}) \\
\text { DSektor } 6: 0.370(-0.170)\end{array}$ \\
\hline Constanta & $0.006 *(1.812)$ & $0.000 *(0.767)$ \\
\hline Model test (R Square) & 0.383 & 0.428 \\
\hline-2 log likehood & 112.810 & \\
\hline Chi-Square t-test & $0.000^{*}$ & \\
\hline Hosmer test & 0.007 & \\
\hline Wald test & 0.333 & \\
\hline Fit Test & & $F=0.000^{*}(5.478)$ \\
\hline
\end{tabular}

Hasil analisis yang di dapat dalam penelitian ini berbeda dengan penelitian yang dilakukan di Spanyol oleh Fernandez dan Nieto (2006) yang menjadi dasar dalam penelitian ini. Pada penelitian ini, ternyata seluruh bentuk kepemilikan UMKM di Jawa Timur adalah bentuk kepemilikan keluarga sehingga penelitian ini tidak dapat menjawab hipotesis kedua dan 
ketiga dalam penelitian ini mengenai pengaruh bentuk kepemilikan korporasi dan campuran terhadap keputusan internasionalisasi yang dilakUkan UMKM.

Berdasarkan hasil dari penelitian yang telah dilakukan, model 1 juga tidak mampu mendukung hipotesis satu yaitu pengaruh bentuk kepemilikan keluarga terhadap keputusan internasionalisasi yang dilakukan UMKM. Hal ini didukung dengan hasil dari model 1 yang menunjukkan bahwa keputusan internasionalisasi yang dilakukan UMKM tidak dapat dijelaskan dengan variabel independen yaitu bentuk kepemilikan keluarga melainkan keputusan internasionalisasi dapat dijelaskan oleh variabel - variabel lain di luar model 1. Meskipun model 1 dikatakan tidak fit tetapi salah satu variabel kontrol signifikan yaitu sektor, dengan nilai koefisiennya - 0.479, yang berarti sektor menjadi salah satu variabel yang dapat mempengaruhi UMKM dalam mengambil keputusan internasionalisasi yang akan mereka lakukan.

Secara keseluruhan model 2 dapat memberikan penjelasan bahwa korelasi antar variabel cukup besar dengan nilai $R^{2} 0.428$, sehingga hubungan antar variabel saling mempengaruhi dan dapat menjelaskan pengaruh semua variabel terhadap intensitas expor yang dilakukan oleh UMKM. Di model 2 ini bentuk kepemilikan keluarga juga tidak dapat menjelaskan pengaruhnya terhadap intensitas ekspor UMKM, sedangkan sektor konsumsi secara signifikan memberikan pengaruh terhadap intensitas ekpor yang dilakukan oleh UMKM dengan tingkat signifikansi 3.7\%. Dari hasil diatas memberikan informasi bahwa untuk hipotesis keempat juga tidak terdukung, hanya saja pemilihan sektor signifikan terhadap intensitas expor dengan hubungan yang negatif.

Dari penelitian yang telah dilakukan dapat dijelaskan bahwa pemilihan sektor merupakan salah satu hal yang penting dalam penentuan pengambilan keputusan internasionalisasi dan intensitas ekspor yang di lakukan oleh UMKM. Hal ini dapat dijelaskan bahwa UMKM melakukan keputusan internasionalisasi berdasarkan kemampuan personal atau sumber daya manusia yang mereka miliki dan kuasai, sehingga pemilihan sektor yang sesuai dengan sumber daya manusia yang mereka miliki dan kuasai akan menempatkan kekuatan daya saing UMKM dalam melakukan ekspor dan sekaligus memberikan kepercayaan diri pada UMKM.

Sektor konsumsi memiliki peran yang negatif pada pengambilan keputusan UMKM dalam melakukan internasionalisasi dan intensitas export UMKM. Hal ini dapat dijelaskan bahwa pimilihan sektor yang dilakukan oleh UMKM tidak berfokus pada salah satu jenis produk yang dapat mereka propduksi, melainkan mereka akan lebih tergantung kepada produk yang 
dipesan oleh pelanggan sehingga mereka akan menyesuaikan produk yang akan mereka produksi dengan keinginan oleh pelanggan (by order).

Bentuk kepemilikan keluarga memiliki beberapa kelemahan apabila di bandingkan dengan bentuk kepemilikan lainnya, salah satunya pada akses pendanaan yang terbatas atau dapat dikatakan kurang. Untuk itu pemilihan sektor menjadikan salah satu cara untuk menutupi kelemahan yang dimiliki oleh bentuk kepemilikan keluarga. Dengan pemilihan sektor yang tepat, UMKM dapat memaksimalkan sumber daya manusia yang mereka miliki dan kuasai untuk bersaing dengan pasar di luar negeri. Selain itu sektor yang dipilih juga dapat dipandang sebagai pembelajaran UMKM dalam melakukan proses internasionalisasi yang dapat membuat UMKM semakin berkembang dengan berjalannya waktu (Fernandez dan Nieto, 2006). Buckley dan Casson (1976) dan Dunning $(1977,1981)$ menyatakan bahwa electic theory dalam strategi internasionalisasi lebih menekankan pada sumber daya yang dimilikinya dan pengetahuan UMKM dalam menentukan pasar dan jaringan yang akan dipilih dalam memasarkan produknya. Berdasarkan pemahaman itulah pemilihan sektor UMKM menjadi penting dalam menentukan keputusan UMKM untuk melakukan internasionalisasi dan intensitas ekspor yang telah mereka lakukan.

Penelitian ini juga menemukan bahwa ada beberapa UMKM yang tidak melakukan kegiatan ekspor secara langsung, tetapi mereka melakukan kegiatan ekspor dengan bantuan dari pengempul untuk melakukan kegiatan ekspor tersebut. Peran pengepul memberikan dampak positif dan sekaligus memberikan dampak negatif. Dampak positif dari adanya pengepul ini adalah membantu UMKM untuk melakukan kegiatan internasionalisasi. Sedangkan sisi negatif adanya pengepul ini adalah semua informasi hanya dimiliki oleh pengepul itu sendiri, sehingga UMKM hanya sekedar mendapatkan perintah atau pesanan dari pengepul dan tidak mendapatkan pesanan secara langsung.

\section{SIMPULAN}

Berdasarkan penelitian yang telah dilakukan ini maka dapat disimpulkan sebagai berikut :

1. Struktur kepemilikan UMKM di Jawa Timur seluruhnya dimiliki oleh keluarga.

2. Struktur dan bentuk kepemilikan keluarga tidak dapat memberikan penjelasan mengenai pengaruh keterlibatan UMKM dalam pengambilan keputusan internasionaliasasi, sehingga dengan ini menjadikan hipotesis tidak dapat terjawab. Variabel yang berpotensi mempengaruhi pengambilan keputusan UMKM untuk melakukan internasionalisasi UMKM adalah sektor dan memiliki peran yang negatif signifikan. 
3. Struktur kepemilikan juga tidak dapat menjelaskan pengaruhnya terhadap intesitas ekspor yang dilakukan oleh UMKM dan sektor industri dalam bidang konsumsi berperan secara signifikan terhadap intensitas ekspor UMKM.

4. Pemilihan sektor industri pada UMKM memberikan proses pembelajran UMKM untuk dapat terus berkembang dan menjadi salah satu penentu dalam pengambilan keputusan internasionalisasi yang akan mereka lakukan.

Keterbatasan Penelitian

Dalam menyelesaikan penelitian ini, terdapat keterbatasan - keterbatasan sebagai berikut :

1. Penelitian ini merupakan replikasi dari penelitian yang dilakukan oleh Fernadez dan Nieto (2006) mengenai keterlibatan internasional UMKM yang terdapat di Spanyol, sehingga adanya perbedaan dalam metodologi yang dilakukan dikarenakan karakteristik UMKM di Jawa Timur berbeda dengan karakteristik UMKM di Spanyol.

2. Pemilihan variabel struktur kepemilikan kurang tepat untuk menjelaskan keputusan UMKM untuk melakukan internasionalisasi.

3. Penelitian ini tidak mempertimbangkan faktor diluar UMKM yang ternyata memberikan kontribusi yang cukup besar dalam mempengaruhi keputusan UMKM untuk melakukan kegiatan internasionalisasi.

4. Penelitian ini tidak memasukkan aspek siklus hidup UMKM yang dapat membantu menentukan orientasi internasionalisasi yang dipilih oleh UMKM.

Saran

Saran yang dapat digunakan berdasarkan penelitian yang telah dilakukan ini adalah sebagai berikut:

1. Permerintah dalam hal ini Departemen Koperasi dan Usaha Mikro, Kecil, dan Menengah perlu melakukan kajian ulang mengenai definisi skala guna memperkuat potensi UMKM agar semakin baik kinerja yang di dapat ditunjukkan oleh UMKM.

2. Potensi penguatan UMKM dapat dilakukan melalui orang tua angkat dalam bentuk joint venture guna memperkuat UMKM dalam hal akses pendanaan dan keputusan investasi yang tepat, meskipun alternatif ini membutuhkan kajian lebih lanjut.

\section{DAFTAR REFERENSI}

Allen, J. and Phillips, G.M., (2000) 'Corporate equity ownership, strategic alliances and product market relationships', Journal of Finance 55(6): 2791-2815. 
Ang, J.S, Cole, R. A., and Lin, J.W., (2000), 'Agency Costs and Ownership Structure', The Journal of Finance Vol. LV. No.1 February 2000: 81-106.

Bonaccorsi, A. (1992) 'On the relationship between firm size and export intensity', Journal of International Business Studies 23(4): 605-635.

Buckley, J, \& Casson, M (1976), The Future of the Multinational Enterprise, Macmillan: London.

Davis, J.H., Schroorman, F.D., \& Donaldson, L.,(1997), "Toward a Stewardship Theory of Management', Academy of Management Review, 22(1): 20-47.

Dunning, J.H. (1977) 'Trade, location of economic activity and the multinational enterprise: a search for an eclectic approach', in B. Ohlin, P.O. Hesselborn and P.M. Wijkman (eds.) The International Allocation of Economic Activity, Macmillan: London.

Dunning, J.H. (1981), International Production and the Multinational Enterprise, Allen \& Unwin: London.

Fama, E.F. and Jensen, M.C. (1985), 'Organizational forms and investment decisions', Journal of Financial Economics 14(1): 101-119.

Fernandez, Z. and Nieto, M.J., (2006), 'Impact of ownership on the international involvement of SMEs', Journal of International Business Studies 37(3): 340-351.

Gillan,S.L. \& Stark, L.T. (2000), 'Corporate Governance Proposals and Shareholder Activism: The Role of Institutional Investors', Journal of Financial Economics 57(2): 275-305.

Gorton, G. \& Schmid, F.A.,(2000), 'Universal Banking and The Performance of German Firms', Journal of Financial Economics 58(1/2): 29-80.

Jensen, M.C., and Meckling, W.H., (1976), 'Theory of the firm: managerial behavior, agency costs and ownership structure', Journal of Financial Economics 3(4): 305-360.

KOMPAS, 14 Desember 2007, 'Usaha Mikro: Akselerasi Pembiayaan UMKM' oleh Djoko Retnadi (2007).

KOMPAS, 29 Februari 2008, 'Fokus: Masalah Besar di Usaha Kecil', (2008).

Knight, G., (2001), 'Entrepreneurship and strategy in the international SME', Journal of International Management 7(3): 155-172.

LU, J.W. and Beamish, P.W., (2001), 'The internationalization and performance of SMEs' Strategic Management Journal 22(6/7): 565-586.

Luo, X., Chung, C.N., Sobczak, M., (2009), 'How Do Corporate Governance Model Differences Affect Foreign Direct Investment in Emerging Economies?', Journal of International Business Studies 40(3): 444-467.

Poza, E. (2004), Family Business, Thomson South-Western Publishing, Mason: Ohio.

Shrader, R.C., and Simon, M., (1997), 'Corporate versus independent new ventures: resource, strategy and performance differences', Journal of Business Venturing 12(1): 47-66.

Shleifer, A., \& Vishny, R., (1997), 'A Survey of Corporate Governance', Journal of Finance, 52(2): 737-783. 
Snkovics, Cavusgil, Roath, 2007, 'Overcoming Export Manufacturers' Dilemma in International Expansion', Journal of International Business Studies 38(2): 283-302.

Thomsen, S. and Pedersen, T., (2000), 'Ownership Structure And Economic Performance In The Largest European Companies', Strategic Management Journal 21 (6): 689-705.

Wright, P.,Feris., S.P ., Sarin A., \& awasthi,V., (1996), 'Impact of Corporate Insider, Blockholder, and Institutional Equity Ownership on Firm Risk Taking', Academy Management Journal 39(2): 34-48.

UU pasal 6 No. 20 tahun 2008 tentang UMKM 